\title{
First record of Amphisbaena mertensi Strauch, 1881 (Squamata: Amphisbaenidae) in Minas Gerais state, Brazil
}

\author{
Adriano Lima Silveira ${ }^{1^{*}}$, Vera Lucia de Campos Brites ${ }^{2}$ and Raquel Valinhas e Valinhas ${ }^{3}$ \\ 1 Universidade Federal do Rio de Janeiro, Museu Nacional, Setor de Herpetologia, Departamento de Vertebrados. Quinta da Boa Vista, São \\ Cristóvão. CEP 20940-040. Rio de Janeiro, RJ, Brazil. \\ 2 Universidade Federal de Uberlândia, Instituto de Biologia. Campus Umuarama, bloco 2D, Rua Ceará, s/n, Umuarama. CEP 38402-018. Uberlândia, \\ MG, Brazil. \\ 3 Centro Universitário de Patos de Minas, Laboratório de Zoologia. Rua Major Gote, oㅡ 808, Caiçaras. CEP 38702-054. Patos de Minas, MG, Brazil. \\ * Corresponding author. E-mail: biosilveira@yahoo.com.br
}

\begin{abstract}
We present here the first record of Amphisbaena mertensi in Minas Gerais state, southeastern Brazil. Through analysis of scientific collections, we found specimens of $A$. mertensi from municipalities of Patos de Minas, Uberaba, Indianópolis, Uberlândia and Araguari, in Triângulo Mineiro and Alto Paranaíba regions. These localities are inserted in the Cerrado biome, with Atlantic Forest enclaves, and represent an expansion of the previously known geographic distribution for the species.
\end{abstract}

The known geographic distribution of Amphisbaena mertensi Strauch, 1881 includes northeastern Argentina, southern Paraguay and Brazil, in southern Mato Grosso, south of Goiás, Mato Grosso do Sul, São Paulo, Paraná and northeast of Santa Catarina states (Gans 1966; Montero 1996; Montero and Terol 1999; Pramuk and Alamillo 2003; Ribeiro et al. 2007). A map showing the previously known geographic distribution of $A$. mertensi was presented by Ribeiro et al. (2007).

There are no records of Amphisbaena mertensi in the Brazilian state of Minas Gerais, where another seven species Amphisbaena are recorded: A. alba Linnaeus, 1758, A. anaemariae Vanzolini, 1997, A. dubia L. Müller, 1924, A. pretrei Duméril and Bibron, 1839, A. prunicolor (Cope, 1885), A. vermicularis Wagler, 1824 and A. wiedi Vanzolini, 1951 (cited as A. fuliginosa wiedi) (Amaral 1935; Vanzolini 1955; 2002; Gans 1962; 2005; Peters and Orejas-Miranda 1970; Vrcibradic and Soares 1999; Barros Filho et al. 2005; Evers Jr. et al. 2006; Recoder and Nogueira 2007; Silveira 2007). We present the first record of $A$. mertensi for Minas Gerais state, in the Triângulo Mineiro and Alto Paranaíba regions, which represents an expansion of the previously known geographic distribution for the species.

Analyzing the Coleção de Répteis do Museu Nacional / Universidade Federal do Rio de Janeiro (MNRJ), we found the following specimens of Amphisbaena mertensi with their localities of origin in Minas Gerais state and collection data: MNRJ 17298 - Municipality of Patos de Minas: City of Patos de Minas: Caiçaras neighborhood (ca. 18 $34^{\circ}$ S, $46^{\circ} 30^{\prime} \mathrm{W}$ ), collected in September, 2008 by R. V. Valinhas; MNRJ 12473 (Figure 1) - Municipality of Patos de Minas, collected in 15 August, 1947 by Egler and Feio; MNRJ 7219 - Municipality of Uberaba: District of Peirópolis (ca. 19²4 ' S, $47^{\circ} 44^{\prime} \mathrm{W}$ ), collected in 1958 by Price; MNRJ 12471, 12472 - Municipality of Indianópolis: Miranda Hydroelectric Power Plant (ca. $18^{\circ} 55^{\prime}$ S, $48^{\circ} 02^{\prime}$ W), collected in August 1997 by L. B Nascimento; MNRJ 18271 - Municipality of Uberlândia: City of Uberlândia: Osvaldo Rezende neighborhood, Marques Póvoa street ( $c a .18^{\circ} 55^{\prime} \mathrm{S}, 48^{\circ} 17^{\prime}$ W), collected in 13 January 1986 by M. C. V. Lemos; MNRJ 18272 (Figure 2) - Municipality of Uberlândia: City of Uberlândia: Lídice neighborhood (ca. 1855' S, 48¹6’ W), collected in 04 April 1987; MNRJ 18274 - Municipality of Uberlândia: City of Uberlândia: Umuarama neighborhood (ca. $18^{\circ} 52^{\prime} \mathrm{S}, 48^{\circ} 16^{\prime} \mathrm{W}$ ), collected in 11 September 1986 by W. P. Souza and H. P. Souza; MNRJ 18273 - Municipality of Araguari: City of Araguari: Tamoios street (ca. 18³9' S, $48^{\circ} 11^{\prime} \mathrm{W}$ ), collected in 27 October 1987 by D. Couto.

The region of these localities is inserted in the Cerrado biome (with its various phytophysiognomies), but has enclaves of the Atlantic Forest biome (semideciduous seasonal forest). The record of the species in Patos de Minas represents an expansion of its' known geographical distribution around $200 \mathrm{~km}$ northeast from the closest previous locality record (municipality of Igarapava, state of São Paulo; Gans 1966) (Figure 3).

We analyzed the main extern morphologic characters of seven specimens recorded from localities in Minas Gerais state (Table 1). The other two specimens were not analyzed because they were loaned to another researcher. The variation found was within the known to Amphisbaena mertensi (Gans 1966; Vanzolini 2002; Ribeiro et al. 2007), except the number of tail scales of a specimen (32 scales) which was slightly larger (25-31 scales), and the tail length in another one $(67 \mathrm{~mm})$, higher than the described (17-65 $\mathrm{mm}$; Gans 1966).

New records of Squamata, including amphisbaenians, have been frequent in the state of Minas Gerais in the recent years, resulting from wildlife surveys on the field and analysis of herpetological collections (e.g. Silveira 2004; Silveira et al. 2004a, b, c; Barros Filho et al. 2005; Silveira and Cotta 2006a, b; Silveira 2007). This shows the lack of knowledge about the composition of the Squamata fauna in this state, despite the existence of recent efforts to reverse this situation. In this context, new records of Squamata are still expected for Minas Gerais. 
(A)

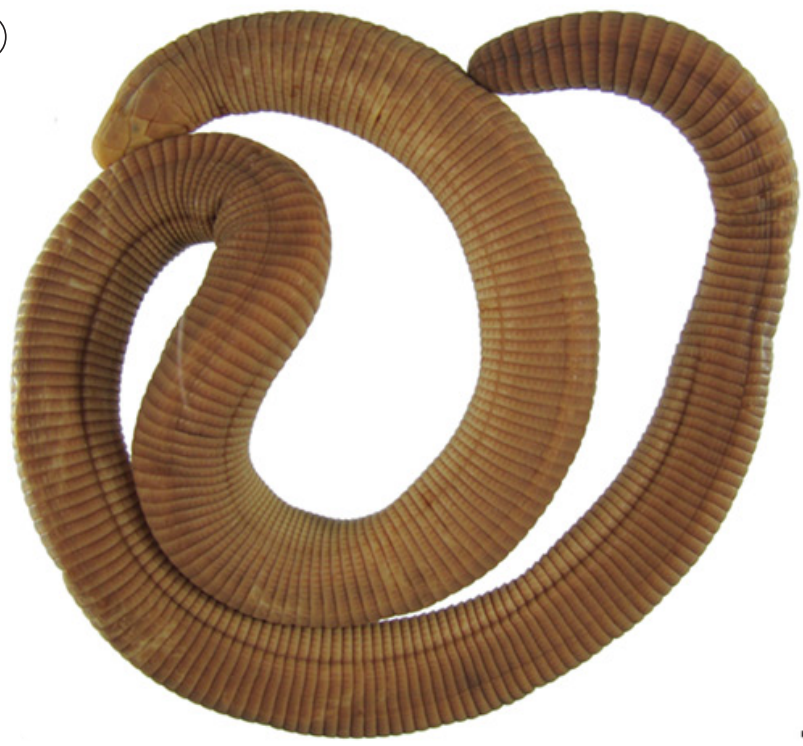

(B)

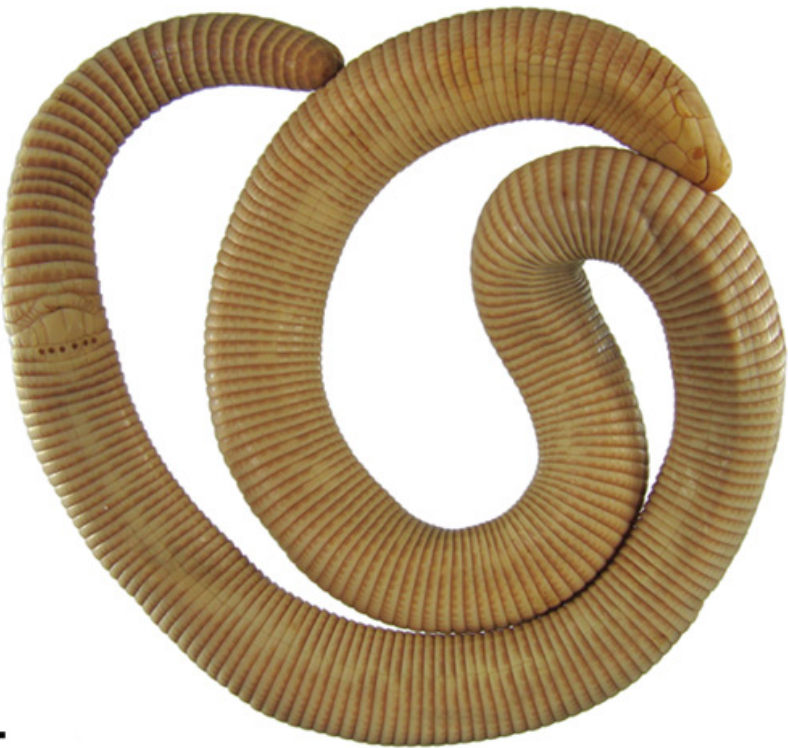

FiguRE 1. Specimen of Amphisbaena mertensi collected in Patos de Minas, Minas Gerais (MNRJ 12473). Dorsal (A) and ventral (B) overview. Scale bar: $5 \mathrm{~mm}$.
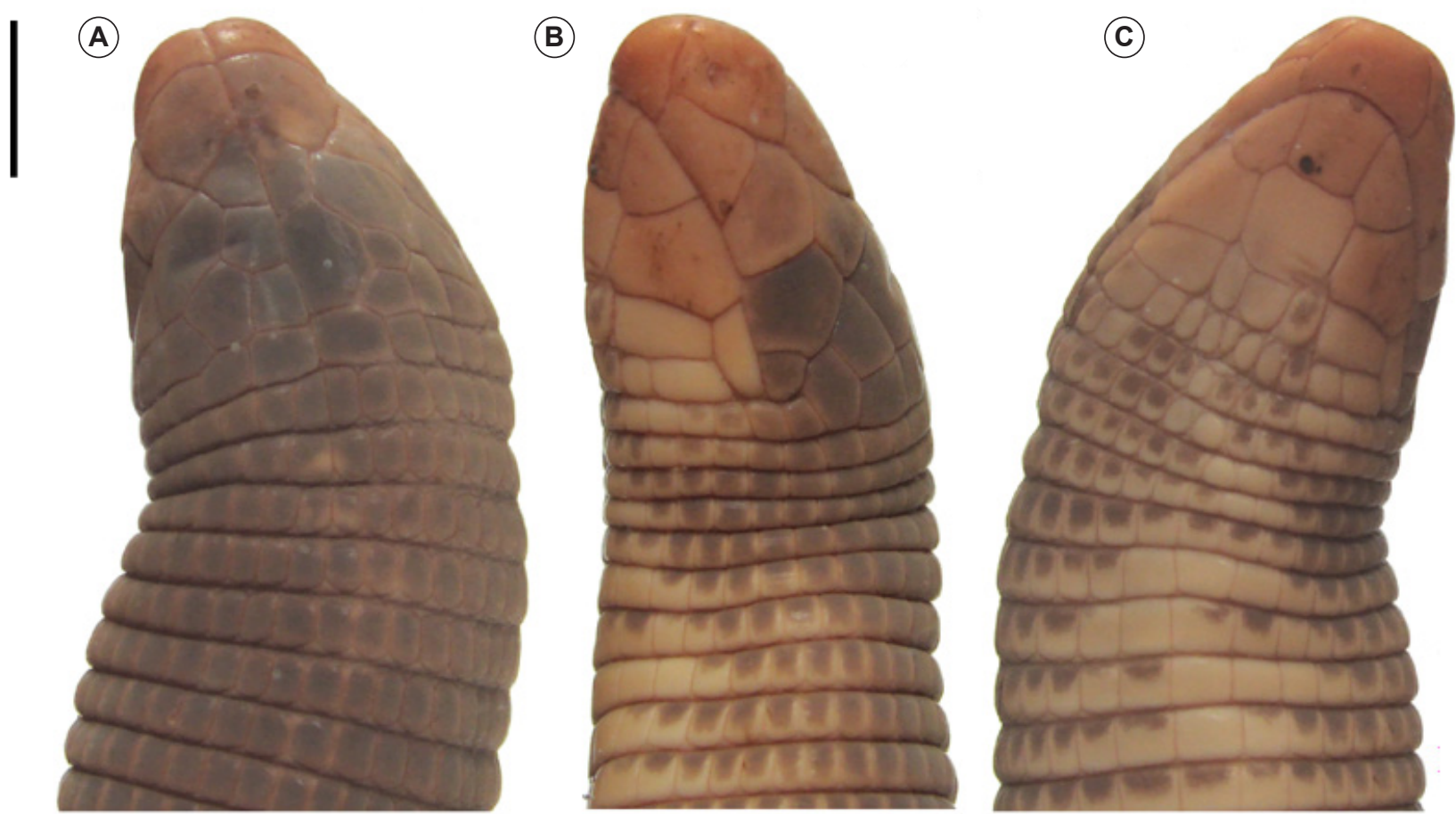

FIGURE 2. Specimen of Amphisbaena mertensi collected in Uberlândia, Minas Gerais (MNRJ 18272). Head in dorsal (A), lateral (B) and ventral (C) view. Scale bar: $5 \mathrm{~mm}$.

TABLE 1. Scales count and measurements (in millimeters) of Amphisbaena mertensi from Minas Gerais, based on specimens at the MNRJ collection and literature records (Gans 1966; Vanzolini 2002; Ribeiro et al. 2007). A bar distinguishes left and right counts of the specimen, respectively; modal values are in parentheses.

\begin{tabular}{lcccccccc}
\hline \multicolumn{1}{c}{ CHARACTERS } & MNRJ & MNRJ & MNRJ & MNRJ & MNRJ & MNRJ & MNRJ & LITERATURE \\
& $\mathbf{7 2 1 9}$ & $\mathbf{1 2 4 7 3}$ & $\mathbf{1 7 2 9 8}$ & $\mathbf{1 8 2 7 1}$ & $\mathbf{1 8 2 7 2}$ & $\mathbf{1 8 2 7 3}$ & $\mathbf{1 8 2 7 4}$ & \\
\hline Pre-cloacal pores & 6 & 6 & 6 & 6 & 6 & 6 & 5 & $5-8(6)$ \\
Body annuli & 239 & 234 & 238 & 237 & 240 & 234 & 235 & $210-250$ \\
Tail annuli & 31 & 32 & 30 & $*$ & 30 & 30 & 31 & $25-31$ \\
Autotomy site & 8 & 7 & 7 & 7 & 7 & 7 & 8 & $5-8(7)$ \\
Dorsal midbody segments & 20 & 20 & 20 & 18 & 20 & 20 & 21 & $14-26$ \\
Ventral midbody segments & 22 & 20 & 22 & 21 & 22 & 21 & 22 & $16-25$ \\
Supralabials & $3 / 3$ & $3 / 3$ & $4 / 3$ & $3 / 3$ & $4 / 4$ & $3 / 3$ & $3 / 3$ & $3-4$ \\
Infralabials & $3 / 3$ & $3 / 3$ & $3 / 3$ & $3 / 3$ & $3 / 3$ & $3 / 3$ & $3 / 3$ & $3-4$ \\
Snout-vent length & 262 & 144 & 318 & 320 & 398 & 168 & 402 & $131-410$ \\
Tail length & 45 & 22 & 49 & $*$ & 64 & 26 & 67 & $17-65$ \\
\hline
\end{tabular}




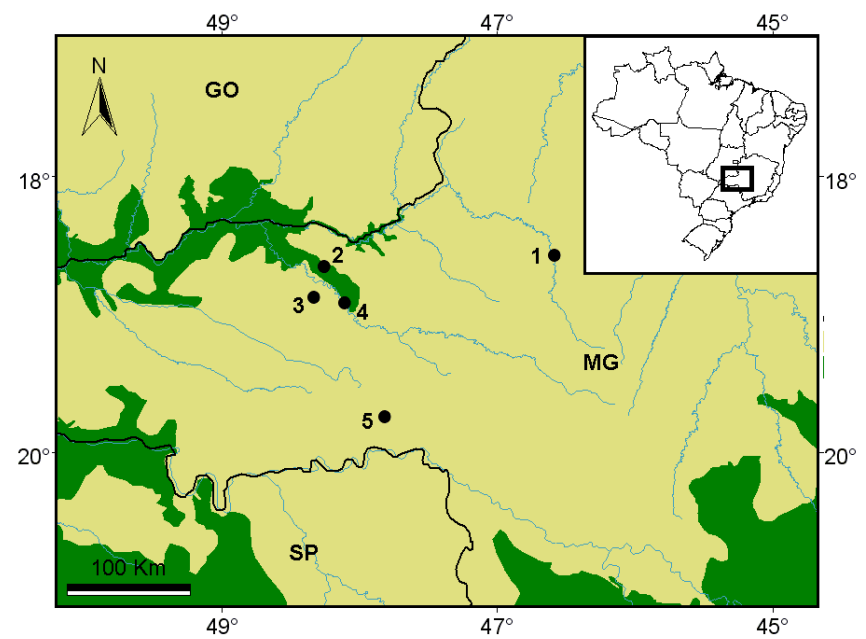

FIGURE 3. Recorded localities (black circles) of Amphisbaena mertensi in the state of Minas Gerais, Brazil: 1 - Municipality of Patos de Minas, 2 Municipality of Araguari, 3 - Municipality of Uberlândia, 4 - Municipality of Indianópolis: Miranda Hydroelectric Power Plant, 5 - Municipality of Uberaba: District of Peirópolis. The Cerrado biome is shown in yellow and the Atlantic Forest biome is shown in green. MG - State of Minas Gerais, SP - State of São Paulo, GO - State of Goiás.

ACKNowledgments: We are grateful to Caio Antônio Figueiredo de Andrade for suggestions.

\section{LiTERATURE Cited}

Amaral, A. 1935. Collecta herpetologica no centro do Brasil. Memórias do Instituto Butantan 9: 233-246.

Barros Filho, J.D., B.M. Sousa and R.M.H. Carvalho. 2005. Geographic distribution: Amphisbaena dubia. Herpetological Review 36(3): 335335.

Evers Jr., P.R., A.L. Silveira and D.S. Lima Filho. 2006. Geographic distribution: Amphisbaena dubia. Herpetological Review 37(2): 240.

Gans, C. 1962. Notes on amphisbaenids (Amphisbaenia, Reptilia). 5. A redefinition and biogeography of Amphsibaena alba Linné. American Museum Novitates 2105: 1-31.

Gans, C. 1966. Redescription of Amphisbaena mertensi, with comments on its geographic variation and synonymy (Amphisbaenia: Reptilia). Copeia 1966(3): 534-548.
Gans, C. 2005. Checklist and bibliography of the Amphisbaenia of the world. Bulletin of the American Museum of Natural History 289: 1-130.

Montero, R. 1996. Lista de localidades de Amphisbaenia de la República Argentina. Cuadernos de Herpetología 10(1/2): 25-45.

Montero, R. and G.J. Terol. 1999. Los Amphisbaenidae en Paraguay, listado geográfico. Cuadernos de Herpetologia 13(1/2): 89-95.

Peters, J.A. and B. Orejas-Miranda. 1970. Catalogue of the Neotropical Squamata: part II lizards and amphisbaenians - with new material by P. E. Vanzolini. United States National Museum Bulletin 297: VIII+25+1-293.

Pramuk, J.B. and H. Alamillo. 2003. An effective technique for collecting Amphisbaena mertensi with notes on its natural history. Herpetological Review 34(3): 221-223.

Recoder, R. and C. Nogueira. 2007. Composição e diversidade de répteis na região sul do Parque Nacional Grande Sertão Veredas, Brasil Central. Biota Neotropica 7(3): 267-278.

Ribeiro, S.L.B., A.P. Santos Jr. and W. Vaz-Silva. 2007. Reptilia, Squamata, Amphisbaenidae, Amphisbaena mertensi: distribution extension, new state record, geographic distribution map. Check List 3(2): 84-87.

Silveira, A.L. 2004. Geographic distribution: Rhachidelus brazili. Herpetological Review 35(4): 412.

Silveira, A.L. 2007. Geographic distribution: Amphisbaena fuliginosa wiedi. Herpetological Review 38(4): 481.

Silveira, A.L. and G.A. Cotta. 2006a. Geographic distribution: Clelia quimi. Herpetological Review 37(2): 242.

Silveira, A.L. and G.A. Cotta. 2006b. Geographic distribution: Thamnodynastes sertanejo. Herpetological Review 37(3): 364.

Silveira, A.L., E.R. Costa and L.M. Salles. 2004a. Geographic distribution: Lystrophis nattereri. Herpetological Review 35(4): 412.

Silveira, A.L., M.R.S. Pires and G.A. Cotta. 2004b. Geographic distribution: Echinanthera melanostigma. Herpetological Review 35(4): 410.

Silveira, A.L., M.R.S. Pires and G.A. Cotta. 2004c. Geographic distribution: Leptotyphlops dimidiatus. Herpetological Review 35(4): 411.

Vanzolini, P.E. 1955. Contribuições ao conhecimento dos lagartos brasileiros da família Amphisbaenidae Gray, 1825. 5. Distribuição geográfica e biometria de Amphisbaena alba. Arquivos do Museu Nacional 42(2): 683-705.

Vanzolini, P.E. 2002. An aid to the identification of the South American species of Amphisbaena (Squamata, Amphisbaenidae). Papéis Avulsos de Zoologia 42(15): 351-362.

Vrcibradic D. and M. Soares. 1999. Geographic distribution: Amphisbaena anaemariae. Herpetological Review 30(4): 233.

RECEIVED: October 2010

ACCEPTED: December 2011

Published ONLINE: February 2011

EDITORIAL RESPONSIBILITY: Mara Cíntia Kiefer 